\title{
ГРЕЧЕСКИЙ КОФЕ И ТРАДИЦИИ ГРЕЧЕСКОЙ КОФЕЙНИ В СОВРЕМЕННОМ ПОЛИТИЧЕСКОМ ДИСКУРСЕ
}

\begin{abstract}
Статья посвящена кофе и кофейне в новогреческой культуре. Варианты названия кофе у греков встраиваются в определенньй политический дискурс, открываюший различные грани длительного и незавершенного конфликта Греции и Турции. Похожие процессы «переназывания» напитка с использованием этнонима наблюдаются и в других балканских странах. Родивиись из турецүкой традиции, во времена греческого освободительного движения против османского владычества, греческая традиционная кофейня нередко становится местом, где обсуждаются пути развития нового государства и греческой идентичности. В наше время ракурс дискуссий смещается на противостояние различных партий и гендерный вопрос, что приводит к возникновению такого феномена как «женская кофейня», который впервые исследуется в данной статье. "Женская кофейня», с одной стороны, нарушает традицию, но с другой - лишний раз раскрывает неизменные черты и механизмы новогреческой традиционной культуры.
\end{abstract}

Ключевые слова: греческий кофе, кипрский кофе, критский кофе, греческая традиционная кофейня, женская кофейня, политический дискурс, гендерный вопрос

Ссылка при цитировании: Сиднева C.A. Греческий кофе и традиции греческой кофейни в современном политическом дискурсе // Вестник антропологии, 2021. № 3. С. 274-286.

Греческий ритуал употребления кофе соответствует диалогической природе политического дискурса. Это неторопливый процесс, растянутый во времени, совпадающий с часами досуга. Обсуждение актуальных общественно-политических проблем в Греции часто происходило и происходит за маленькой чашечкой «греческого кофе» дома или в кофейне. Кофе в Греции - яркий пример заимствованной из османского, исламского мира, но глубоко укорененной на греческой почве, традиции. Традиционная греческая кофейня - продукт сложных кросскультурных влияний, прежде всего восточных, но также и западных, которые привели к новым вариантам заведения в XXI в. В данной статье предпринимается попытка рассмотреть проблему в ракурсе политического конфликта и взаимодействия на межэтническом уровне, так и внутри греческого социума.

Сиднева Светлана Александровна - к.ф.н., доцент кафедры итальянского языка факультета иностранных языков и регионоведения, МГУ имени М.В. Ломоносова (119991 Москва, Ленинские горы, д. 1, стр. 13). Эл. почта: lucia1980@yandex.ru. ORCID: https://orcid.org/0000-0002-2937-5434 
К роли напитков и шире - еды в государственной политике стран, истории революций и национальных течений, самоопределении народа обращались многие исследователи, как зарубежные, так и отечественные.

Обобщающую характеристику места пищи в цивилизационных процессах, таких как торговля, войны, появление социального и гендерного неравенства, дала А. В. Павловская в статье «Нужна ли нам наука о еде?» (Павловская 2015: 9). В этой же работе автор остановилась на особой роли пищи и напитков в историческом и актуальном политическом дискурсе, когда еда «была призвана стать символом - сопротивления, противоборства, протеста, и использовалась для привлечения максимального внимания широких масс к проблеме (например, Бостонское чаепитие или нынешнее продовольственное эмбарго3)» (Павловская 2015: 36). Бостонское чаепитие вывело на политическую сцену чай и кофе: американцы отказывались пить напиток, ставший символом британской метрополии, и демонстративно переходили на кофе.

О.Д. Фаис-Леутская и М.Ю. Мартынова в статье «Антропология питания: судьбы мясных деликатесов в Европе» отмечают, что определенные блюда и напитки нередко являются маркерами национальной идентичности и становятся символами политических движений. В частности, авторы ссылаются на работу П. Алонсо Гонсалеса, исследовавшего роль вина в субкультуре сепаратистского движения басков в Испании (Мартынова, Фаис-Леутская 2019). По отношению к Греции, можно говорить об особой роли кофеен в освободительном движении против османского владычества и позднее в борьбе различных партий, пытавшихся решить судьбу молодого греческого государства в XIX в. и отличавшихся профранцузскими, пробританскими или прорусскими интересами. В XX в. кофе, а точнее принципы его номинации у греков становятся символом протеста против оккупационной политики Турции на о. Кипр. Именно этот лингво-культурно-политический аспект остается недостаточно изученным в научной литературе, хотя и освещен в заметках греческих и зарубежных журналистов, книгах и блогах специалистов по греческой пищевой культуре, фиксируется в практике современных греческих кофеен и торговых предприятий, иногда служит для разделения членов греческого социума на «свой-чужой» и также становится в своем роде мерилом лояльности или нелояльности представителей других стран к разным сторонам греко-турецкого конфликта.

Проблему отношения кофе и греческой национальной идентичности греков рассматривал этнограф А.П. Попов, занимавшийся изучением греческих диаспор вне Греции и, в частности, понтийских греков на территории России. Он отметил этнодифференцирующую функцию напитка: «употребление кофе расценивается как преимущественно кавказская черта, и иногда как отличие понтийских греков как “кавказцев” от окружающего русского населения, например в качестве самоиронии - “скупой грек гостя кофем напоил, гущей накормил”» (Попов 2020). Примечательно, что в этом случае понтийские греки, благодаря кофе, включены в кавказский контекст. Кроме того, при помощи кофе транслируется стереотип о «скупом греке», который по всей видимости, противопоставляется «широкой русской душе» ${ }^{1}$. Иначе дело обстоит с данными функциями напитка в самой Греции. Ритуал, когда гостю

${ }^{1}$ А.П. Попов и путешественники, оставившие записки о понтийских греках, проживавших на русском Кавказе, действительно отмечали бережливость и некоторую скупость этого народа, объясняемую стесненными обстоятельствами. Особенно экономично приходилось жить переселенцам из Трапезунда и Карса в Ставропольском крае. Эти факты подтверждают и мои информанты из греческой общины Минвод и живущие рядом с общиной русские (ПМА 2005). 
предлагают чашечку кофе, скорее отсылает к понятию греческого гостеприимства $(\varphi \imath \lambda o \xi \varepsilon v i \alpha)$ в его почти архаичном смысле священного и неприкосновенного гостя. Преимущественное потребление кофе включает греков в алиментарную систему Балкан и Средиземноморья. В плане номинации популярного напитка греки следуют общему для многих балканских стран «политическому» принципу, основанному на идее, близкой к культурной апроприации.

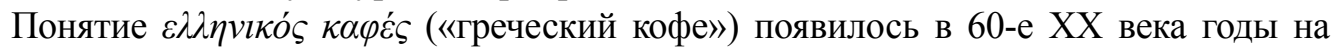

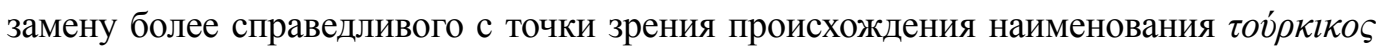

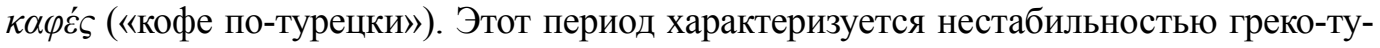
рецких отношений ${ }^{1}$. События, связанные с оккупацией северной части Кипра турками в 1974 году, обострили извечный греко-турецкий конфликт и привели к тому, что частные случаи политической номинации превратились в правило. Греческий журналист и специалист по пищевой культуре, активно продвигавший бренд греческой кухни в мире и писавший под говорящим псевдонимом Epicuros, Альберт Аpoy (Albert Arouh), говорил о том, что до 60-х годов кофе называли турецким, тогда как в 80-х годах даже считалось почти неполиткорректным заказывать в греческих кофейнях «кофе по-турецки». Наименование греческий кофе употреблялось, как в быту, так и в рекламных компаниях, например, греческой кофейной компанией «Bravo», впоследствии поглощённой голландской компанией «DE Master Blenders 1753». Слова Альберта Ароу зафиксировала другая греческая журналистка Джоанна Какиссис в своем блоге Тhe Salt, посвященном кухням мира (Kakissis 03.09.2020). Эти же факты упоминает в своем исследовании политолог Л. Каракацанис и добавляет, что в политических диспутах греков наименования греческий и турецкий кофе используются, чтобы отличить «предателей» от «патриотов» (Karakatsanis 2014: 111). Среди моих информантов наблюдалась разница отношения к номинации, в зависимости от возраста. Так, греки из г. Касторья, о. Родос и из Афин старше 40 лет, были склонны считать более лояльным и «своим» человека, который употреблял термин «греческий кофе» и не очень благосклонно реагировали на «кофе по-турецки», старались поправить «неверный вариант». Информанты младшего возраста относились к «ошибке» довольно равнодушно, за редким исключением политически образованных студентов (ПМА 2006, 2009, 2017). Информативной можно считать сцену из известного греческо-американ-

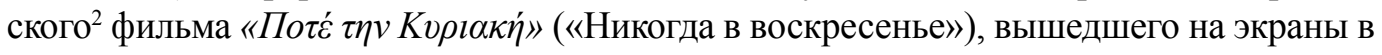
1960 году: американец-интеллектуал приходит в греческую кофейню и Пирее и уточняет, можно ли ему заказать кофе по-американски. Официант резковато отвечает, что есть только кофе по-гречески и приносит поднос с туркой, стаканом воды и маленькой чашкой с тонкими стенками. Резкость тона персонажа становится понятной с точки

\footnotetext{
${ }^{1}$ Конфликт начался еще в 1955 году, когда в ответ на Стамбульский погром, развернутый турками против греческого меньшинства в бывшей столице Византии, греки прервали дипломатические отношения с Турцией. В 60-е годы обострился “кипрский вопрос". На остров, получивший независимый статус в качестве компромиссного решения, высадили греческие и турецкие войска, чтобы “гарантировать защиту и нейтралитет” своих сторон. Однако, жесткая и бескомпромиссная политика турецкого правительства, а также националистическая ориентация хунты черных полковников в Греции привели к кризису отношений, в результате которого после спорадических военных столкновений в 1974 году северная часть Кипра была оккупирована турецкими войсками.

2 Этот фильм, несмотря на режиссуру Жюля Дассена и производство Lopert Pictures Corporation, можно назвать скорее греческим фильмом и не только потому, что большая часть актеров греки, включая главную женскую роль в исполнении национальной греческой актрисы Мелины Меркури, но и потому, что этот фильм воспринимается греками как «свой».
} 
зрения культурного кода, который содержится в этом коротком эпизоде. Когда американец спрашивает, что пьют другие мужчины в кофейне, он получает ответ: «Узо! Вот что пьют мужчины!» Иностранец как бы дважды нарушает этикет греческой кофейни: просит американский кофе - некрепкий с большим количеством воды, то есть недостойный «настоящего мужчины» и даже не заказывает спиртное. К тому же сцена может расшифровываться и в духе политического дискурса: в греческой кофейне можно заказать только кофе по-гречески. Влияния извне на греческую политику, в том числе и со стороны американцев, воспринимается негативно. И именно в 60 -е годы греческая внутренняя политика берет курс на усиление националистических тенденций в противовес интернационалистским.

Необходимо заметить, что на о. Кипр, этот вариант кофе называют кvлрıкко́ $\kappa \alpha-$ $\varphi \dot{s} \varsigma$ («кипрским кофе»), что лишний раз дифференцирует автономный статус о. Кипра и особенности идентичности греков-киприотов, которые все-таки отделяют себя от материковых греков.

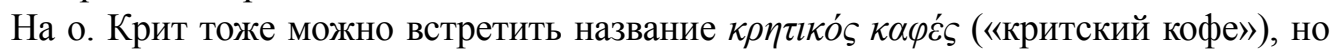
это название не является вариантом политически номенклатурного греческого кофе.

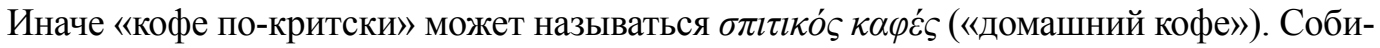

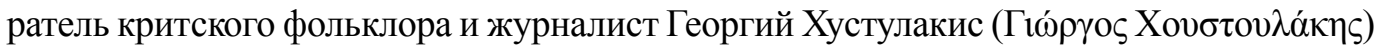
описывает этот напиток, как некую альтернативу привычному кофе. Он приготовлялся в кастрюле или турке на песке, подобно традиционному кофе по-турецки (или по-гречески), но в его состав входили нут, пшеница и плоды рожкового дерева, иногда по-

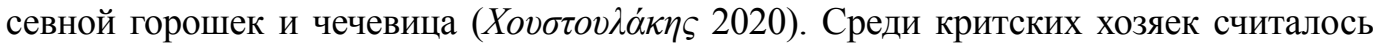
хорошим тоном угостить гостя хотя бы «критским кофе», если средства не позволяли приобрести дорогой настоящий кофе. Информанты вспоминали, что данный напиток использовался и как лечебный при упадке сил или воспалительных процессах разного происхождения, а также как замена кофе в более позднее время (80-е) для людей, которым был противопоказан настоящий кофе из-за высокого давления или проблем с сердечно-сосудистой системой (ПМА 2007). Примечательно, что Хустулакис избегает термина, содержащего этноним, и критскому кофе противопоставляет-

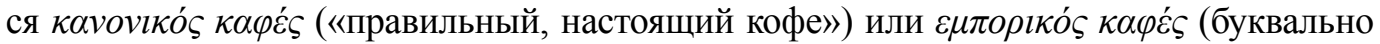
«торговый кофе», то есть кофе, который продавался в кофейнях или магазинах). Такая уклончивость в терминах может считаться, с одной стороны, особенностью островного мышления, с другой стороны знаком некой лояльности Греции, в состав которой входит Крит, так как автор избегает наименований «греческий» и «турецкий» в равной степени. Также на Крите наряду с турецким влиянием было не менее сильно влияние итальянской (венецианской) культуры. Кроме, того, острова обычно более терпимы из-за особенностей географического положения к разным кросскультурным влияниям, и там политический дискурс носит менее острый характер.

В последние время в меню греческих кофеен, особенно ориентированных не только на греков, но и на иностранных туристов, а также в греческих СМИ встречается

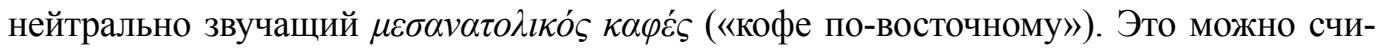
тать компромиссным вариантом и данью уважения авторскому праву, после того как в 2013 году ЮНЕСКО удовлетворило запрос турок на признание определенного способа приготовления кофе нематериальным наследием Турции. Однако, наименование $\varepsilon \lambda \lambda \eta v \iota \kappa o ́ \varsigma ~ \kappa \alpha \varphi \varepsilon ́ \varsigma$ преобладает. Иногда оно теряет остроту политического смысла или, наоборот, актуализирует ее, в зависимости от динамики греко-турецких отношений. 
Между тем, схожий политический дискурс можно встретить и в номинациях, принятых в других странах, бывших под османским владычеством: кофе по-армянски, сербский, боснийский кофе и другие. Однако, некоторые страны пытаются объяснить право так называться, исходя из небольшой разницы приготовления и сервировки (с армянским кофе подают пахлаву, боснийский кофе дважды доводят до кипения, предварительно отливая небольшое количество почти закипевшей воды в кофейную чашку и снова смешивая ее с кофе в турке, и т.д.). Классический способ приготовления «греческого кофе» происходит так: в джезву заливается смесь кофе, воды и сахара, в зависимости от типа напитка, и почти доводится до кипения. Во время подогревания смесь помешивается ложкой или палочкой. Характерной чертой является густая пенка, которая должна образоваться во время кипения и в идеале сохранится при сервировке. Кофе подается в небольшой кофейной чашке с тонкими стенками.

Разновидности «греческого кофе» различаются количеством сахара или его от-

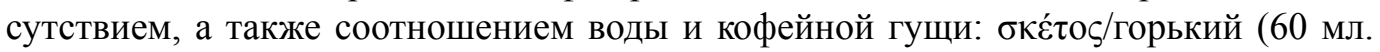
воды + 1 чайная ложка кофе); $\mu \varepsilon$ оді́үๆ/подслащенный (60 мл. воды + 1чайная лож-

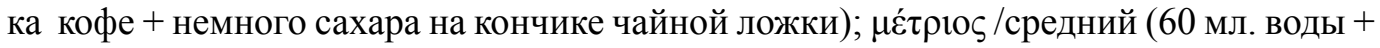
1 чайная ложка кофе+ 1/2 ложки сахара); үлvко́ $/$ сладкий (60 мл. воды +1 чайная

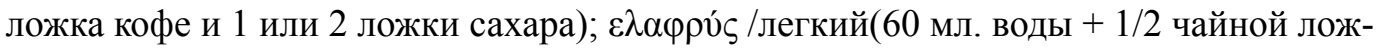

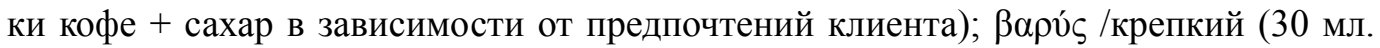
воды +1 ложка кофе+ сахар в зависимости от предпочтений клиента).

Лингво-культурный парадокс наблюдается с другим видом кофейного напитка, который вошел в меню традиционных греческих кофеен с конца 50-х. На Между-

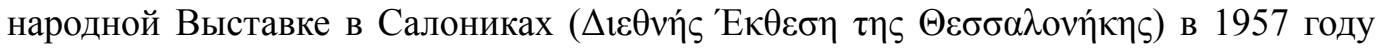
Димитриос Вакондиос изобретает өралє́ (фраппе) - холодный напиток из растворимого кофе со льдом, который взбивается в шейкере. На выставке изобретатель ис-

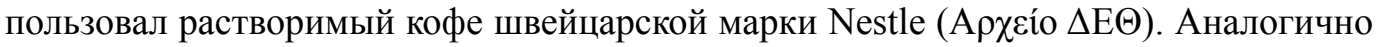
«греческому кофе» существует несколько вариантов подачи кофе, в зависимости от количества сахара. Однако, во фраппе может также добавляться молоко или мороженое. Любопытно, что этот вид кофе приготовлен, в отличие от «греческого», по оригинальной рецептуре, придуманной греком, но в номинации продукта это фиксируется. Для обозначения нового напитка используется французский термин, отображающий способ приготовления ${ }^{1}$, а не его этническую принадлежность, но при этом фраппе становится едва ли не одним из греческих национальных символов. Довольно стереотипным, хотя и не совсем верным, является представление о «ленивых греках», попивающих фраппе в жаркий летний день. Данный стереотип фиксируется в блогах иностранных путешественников, посещающих Грецию, в массовой культуре, голливудской кинопродукции (см., например, фильм 2009 г. «My life in ruins»).

Традиция приготовления «греческого кофе», его сервировка, контекст потребления, безусловно, были заимствованы греками во времена Османской империи. Первые кофейные лавки открывались в XVI в. в завоёванном турками Константинополе. Но уже в XVII веке турецкий хронист и путешественник Эвлия Челеби упоминает о существовании в Салониках большого числа кофеен, которые могли также быть местом встречи представителей разных народов, включая греков, хотя обычно не урумам (отуреченным грекам) вход в турецкую кофейню запрещался.

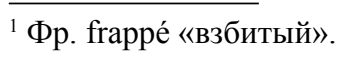


Стоит отметить, что популярность кофейного напитка и праздное времяпрепровождение в кофейне вызвала негативную реакцию мусульманских муфтиев, которые не замедлили издать запрещающие фирманы. В ряде случаев запрет налагался именно на сам напиток, но иногда именно контекст его потребления. Известны, например, указы султана Мурада IV (1623-1640 гг.), вводившего запреты на распитие кофе и спиртных напитков в общественных местах в столице. Султан, вошедший в историю как довольно жесткий и бескомпромиссный правитель, опасался, что кофейни станут местом консолидации янычар и местом подготовки заговоров и бунтов, которыми была отмечена эпоха, предшествующая его правлению (Ведюшкин, Юсим 2013: 226). Ограничения, введенные Мурадом IV, действовали и после его правления, так как Эвлия Челеби отмечает в своих записках тот факт, что многие константинополь-

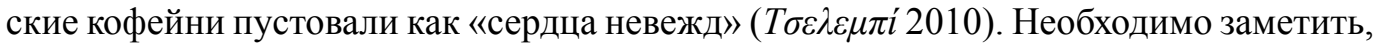
что среди янычар часто бывали греки, набранные в элитное войско султана по девширме («налог кровью»). Однако, это не остановило турок, а грекам дало лишний повод рассматривать употребление кофе почти как некий акт протеста против постановлений мусульманских духовных лиц. У обоих народов кофейня стала не только местом отдыха и развлечения, но и своеобразным политическим клубом, в котором

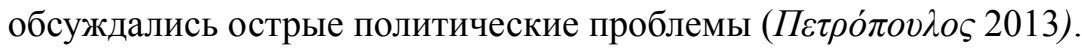

В греческой традиции политическая роль кофейни особенно четко будет выражена в эпоху освободительного движения против турецкого владычества и в ХX в.

В Фессалии упоминается легендарная кофейня И.Е. Форлидаса, открытая в 1785 году. Ее посещали греческие писатели Варналис и Пападьямантис. И это немногочисленная из первых «греческих кофеен», основанных именно греками из семьи Форлидас. Стоит также упомянуть кофейню в Навплионе, которая открылась почти сразу после освобождения от турецкого владычества в 1828. Есть спорное предположение, что ее владельцем был Эммануил Антониадис, отец греческой независимой журналистики и участник Греческой революции 1821-1829 гг. Название кофейни не сохранилось, но есть письмо Антониадиса, в котором он обращается к мэру города по поводу проблемы, связанной с кофейней, расположенной возле фонтана в центре города (Г.А.К.). Это письмо не подтверждает однозначно право собственности Антониадиса, но в газетах того времени упоминаются собрания в одной из кофеен Навплиона, которую часто посещал политический деятель Греции.

Однако ряд греческих кофеен, в которых собирались греки и филэллины, были открыты иностранцами или гражданами нового греческого государства негреческого происхождения. Состав посетителей тоже был интернациональным, а сами заведения скорее напоминали изящные салоны или пивные. Так, кофейня «Про́бıvо $\Delta \varepsilon v \tau \rho i ́ »$ в Афинах была открыта в 1834 баварцами. В отличие от других греческих кофеен, ее могли посещать женщины, правда в определенные дни и часы. Она сочетала традиционные черты турецкой кофейни и немецкой пивной. Не случайно в нее мог зайти даже первый греческий король Оттон, который имел баварское происхож-

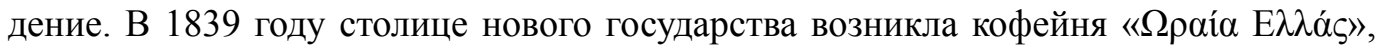
которая постепенно превратилась в настоящий политический клуб для греков, хотя в качестве ее основателя указывается «некий итальянец», к тому же первоначальное название кофейни было итальянским «Bella Grecia». Отличительной чертой такой европейской кофейни от турецкой считалось наличие бильярдного стола. С этой кофейней, тем не менее, связан ряд политических событий. Именно там противники 
монархии демонстративно сжигают промонархисткую газету «Элпис» в знак протеста против внешней политики греческого короля Отона. В этой же кофейне начинается революционное движение в октябре 1862 года, которое приводит к отстране-

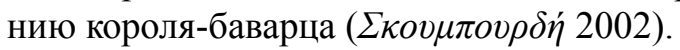

Более «греческими» представляются также некоторые политические кофейни Афин XIX - начала XX вв., сведения о которых можно найти в газетах и литера-

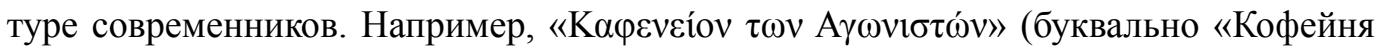

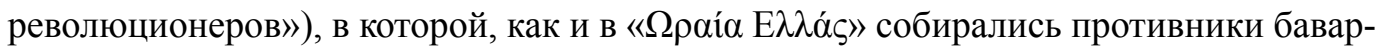
ской оккупации и монархии. Такими же политическими настроениями отличались посетители кофейни Янниса Хавтаса, бывшего участница Греческой революции. Кофейня была закрыта в 1880 году как политически нелояльная правительству. Стоит также упомянуть антимонархические кофейни «Тбочра́лı» (кофейня была назва-

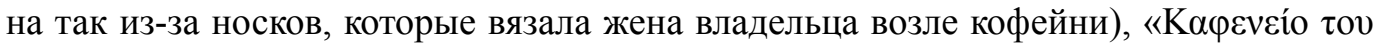

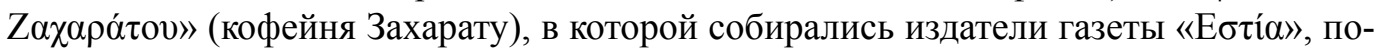
литики, поэты, писатели, среди которых Психарис, Ксенопулос, Дрозини, Паламас,

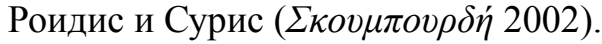

Однако, некоторые из вышеназванных кофейен были синтезом разных традиций

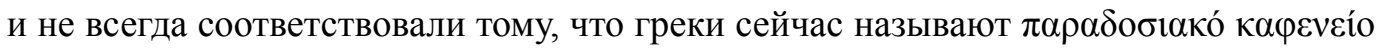
(«традиционная, народная кофейня»), без изящной французской или венской мебели, с ограниченным ассортиментов напитков и закусок.

Для обозначения традиционной греческой кофейни в новогреческом языке ис-

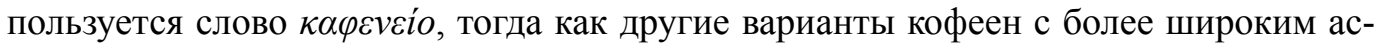

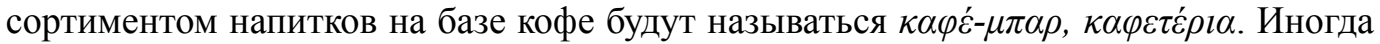

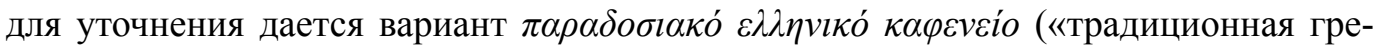
ческая кофейня»), чтобы не было путаницы с другими видами кофеен. «Словарь современного греческого языка» или словарь Бабиньотиса, объединяющий в себе толковый и этимологический словари, довольно точно описывают суть традиционной греческой кофейни:

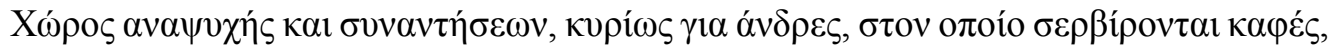

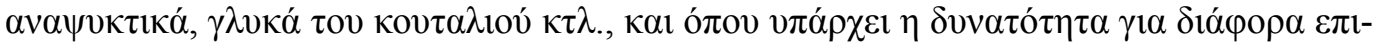

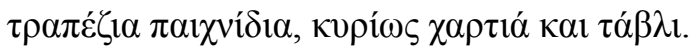

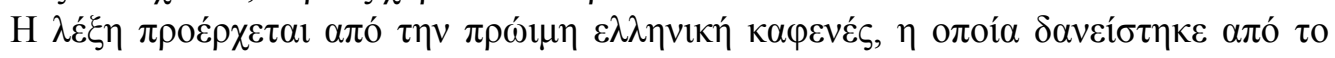

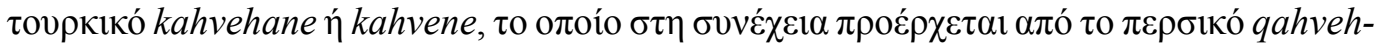

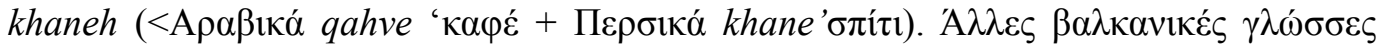

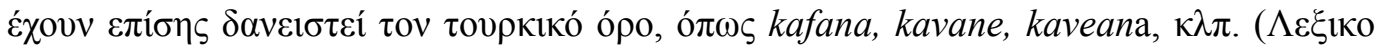

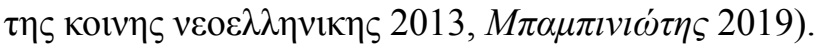

В определениях подчеркивается, что это место отдыха и встреч, главным образом мужчин, в котором подают кофе, сладости, закуски, прохлаждающие напитки. В кофейне можно сыграть в карты или нарды. Этимология слова восходит к тур. kahvehane или kahvene, которое в свою очередь является заимствованием из персидского qahveh-khaneh «дом кофе». Похожее турецкое заимствование обнаруживается и в других балканских языках: kafana, kavane, kaveana.

На Крите для обозначения традиционной кофейни часто используется турецкое заимствование vтovкlóvı, восходящее к турецкому духану (dükkan). Словарь крит-

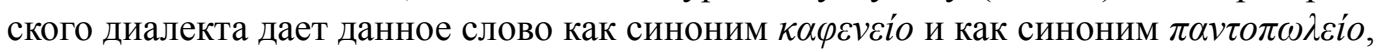
то есть бакалейной лавки, в которой также можно выпить кофе. Это объяснение не 
является противоречием. Традиционная кофейня тоже часто имеет функции бакалейной лавки, особенно в современности. Информанты с Крита также используют вариант, близкий к оригинальному турецкому слову, - кафєvє́ (ср. с тур. kahvene). На уровне языка политический дискурс на острове оказываться менее жестким к месту.

Довольно точно описывает греческую кофейню и ее функции в жизни традиционного патриархального общества исследователь греческой пищевой культуры и автор книг, посвященных греческой кофейной традиции, Г. Питтас:

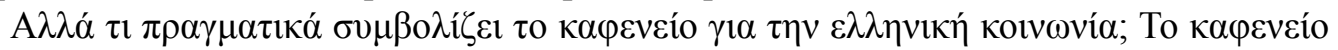

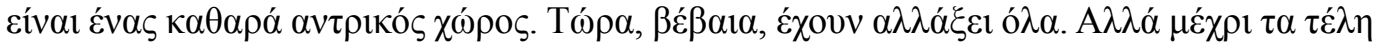

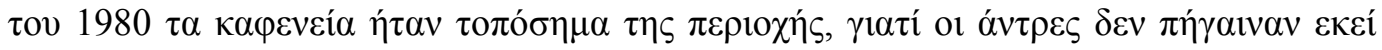

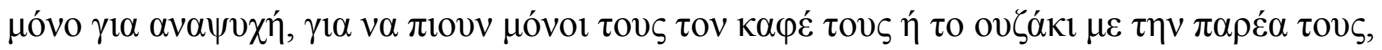

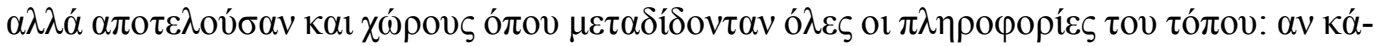

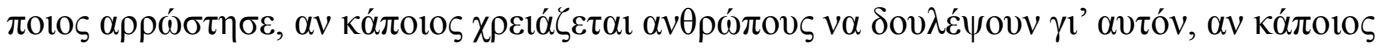

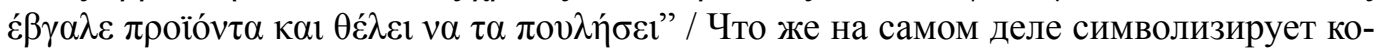
фейня для греческого общества? Когда-то это было исключительно мужское место. Конечно, в наше время все изменилось. Однако, до конца 1980-х кофейни были центром общественной жизни, потому что мужчины ходили в них не только отдохнуть и выпить в одиночестве чашечку кофе или пропустить стакан узо ${ }^{1}$ с приятелями. Там можно было узнать местные новости: вдруг кто-то заболел или ищет работу, а,

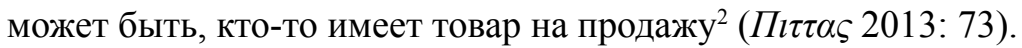

В отличие от турецкой кофейни, греческая традиционная кофейня характеризуется большей аскетичностью интерьера и меньшим разнообразием меню: сладости скорее составляют исключение в данном типе кофейни. Из кофе можно, как уже упоминалось выше заказать разновидности «греческого кофе» и фраппе. Из спиртных напитков наиболее популярными оказываются узо и рецина (белое смоляное вино).

В некоторых греческих регионах фиксируется любопытный гендерный предрассудок, который утверждает, что сладкий кофе пьют женщины, тогда как настоящему мужчине положено пить кофе без сахара. Информант из константинопольских греков, проживавших в Афинах, рассказал характерный политический анекдот, порочащий национального героя турок - Кемаля Ататюрка. «Отец турок» якобы посетил кофейню и заказал, подобно женщине, очень сладкий кофе противным тонким голосом, что должно было вызвать сомнения в мужественности Ататюрка (ПМА 2006).

Традиционная греческая кофейня, восходящая к турецкой кофейне, позаимствовала многие, присущие ей черты, которые будут оспорены в современном политическом дискурсе: например, изначально существовал негласный запрет или ограничения на посещение женщин. Выше цитировался Питтас, назвавший традиционную

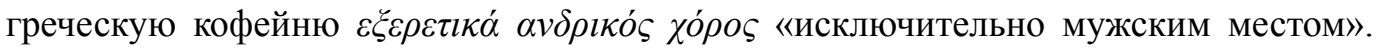
В этом случае обнаруживается любопытное сходство с английскими кофейнями, о которых писал исследователь гендерного вопроса и кофеен Б. Коуэн. Здесь можно говорить, как об общем происхождении кофеен (Восток), так и о типологии патриархальных культур. Однако, Коуэн заметил, что английским женщинам декларативно не запрещалось посещать кофейни, просто им были неинтересны обсуждаемые в кофейнях политические вопросы, тогда как в Греции все-таки сильнее действовали табу и предрассудки патриархальной культуры (Cowan 2005).

\footnotetext{
${ }^{1}$ Бренди с анисовой вытяжкой.

${ }^{2}$ Перевод фрагмента С.А. Сидневой.
} 
Конечно, сейчас нет строгого запрета на посещение традиционной кофейни женщинами, как это было до 1980-х, но в небольших городах или на островах, все равно можно увидеть заведения, основными клиентами которых являются все же пожилые мужчины. Женщины могут выступать в качестве обслуживающего персонала, не появляющегося в основном зале: посудомоек, уборщиц или поваров. Чаще всего это семейные подряды, поэтому указанные функции могут выполнять родственницы хозяина заведения. Стоит отметить, что умение хорошо приготовить кофе у женщин патриархальная традиция одобряла всегда. В традиционной культуре турок, а также понтийских и константинопольских греков существует предсвадебный обряд или обычай во время сватовства, когда девушка должна сварить для будущей свекрови или свахи кофе.

Можно предположить, что в Греции ограниченное посещение женщинами кофейни было также связано с тем, что женщины были довольно долго ограничены в правах избирателей (до 1952 года), а в кофейню нередко приходили представители партий для того, чтобы агитировать избирателей. Об этом упоминают исследователи культуры греческой кофейни Питтас и Петропулос, но также это можно видеть в не-

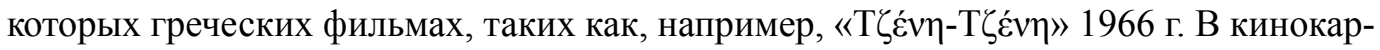
тине присутствует сцена, в которой кандидат в мэры небольшого города-островка Горцос приходит агитировать своих избирателей в традиционную греческую кофейню против своего противника Мандаса. Современные кофейни часто делятся по партийной принадлежности. Например, сторонники греческой компартии КKЕ редко окажутся в одной кофейне со сторонниками греческой социалистической ПА $\mathrm{OK}$ или демократической партии $\mathrm{N} \varepsilon ́ \alpha \Delta \varepsilon \mu о \kappa \rho \alpha \tau i ́ \alpha$ или со сторонниками партии с националистическим уклоном «Хрvби́ Аvүฑ́». Сходный феномен кофейни можно наблюдать во многих балканских странах и на о. Кипр. На Кипре кофейни иногда называ-

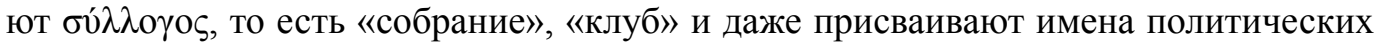
деятелей как греческих (Макариос, Венизелос), так и интернациональных (Маркс).

В этом смысле важным мог оказаться и мотив, упомянутый выше в связи с английскими кофейнями: незаинтересованность женщин в политической проблематике, а также их занятость в повседневных рутинных хозяйственных делах, оставлявших мало место для досуга.

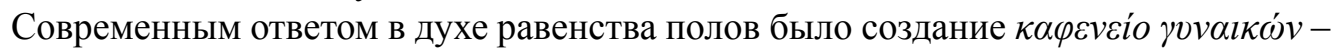
кофейни только для женщин. Рассмотрим несколько характерных примеров.

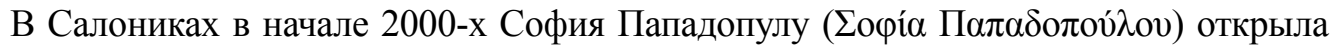

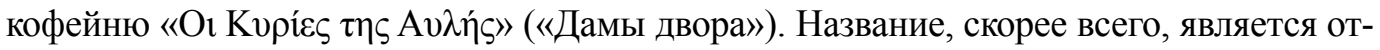
сылкой к фильму 1966 Диноса Димопулоса с аналогичным наименованием. Основной возраст посетительниц - замужние женщины старше сорока лет, которые приходят в кофейню отдохнуть от домашних дел, пообщаться с подругами. Подобная кофейня

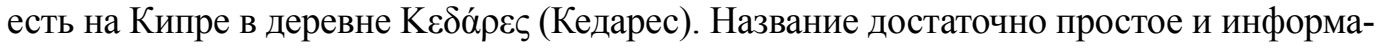

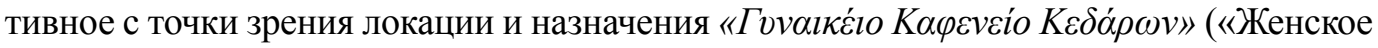
кафе в Кедарес)». У кипрской кофейни нет определенного хозяина в виде физического лица. Она существует за счет ежемесячного взноса женского комитета, состоящего из группы местных жительниц. По эстетике обе кофейни похожи на традиционные, хотя и отличаются большей изысканностью интерьера: цветы на столе, красивые скатерти. Меню, в основном, остается близким к «мужской кофейне», вплоть до наличия спиртных напитков, которые, однако, заказываются ожидаемо реже. 
Реакция греческого общества на феномен «женской кофейни», в целом, позитивная, что отображается в греческих СМИ ${ }^{1}$, отзывах в социальных сетях, вроде Facebook. Но иногда можно отследить и ироничные комментарии, как правило, людей младше соро-

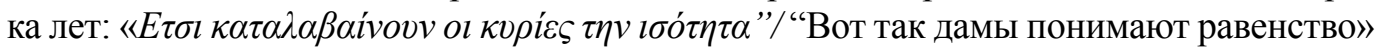
(https://www.newsbeast.gr/greece/arthro/460967/ena-kafeneio-mono-gia-gunaikes). Дело в том, что посещать некоторые кофейни имеют право только женщины, а не представители обоих полов, как следовало бы сделать в духе истинного равенства. К тому же вопросы, обсуждаемые в данной кофейне, часто, хотя и не всегда, имеют некий гендерный уклон, как будто бы ограничивающий женщин определенными сферами жизни: воспитание детей, кухня, шитье, сериалы, мода, домашние проблемы. Так в новом явлении сохраняются черты традиционной греческой культуры.

Более «чистой» в политическом смысле является кофейня в городе Янина

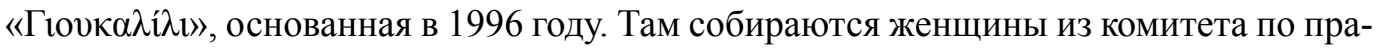
вам женщин и обсуждают вопросы общественно-политического характера. Основа-

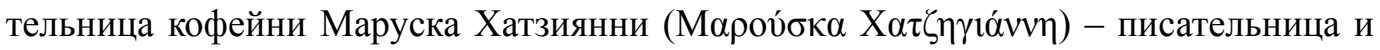

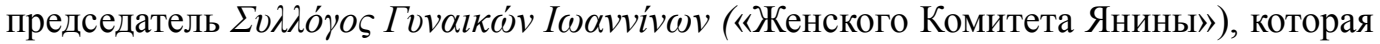
создала кофейню, чтобы, по ее же словам, «дать развитие женским движениям». Хотя она утверждает, что кофейню могут посещать представители обоих полов «без гендерных предрассудков», в итоге большинство посетительниц все-таки женского пола. Название кофейни переводится как «Укулеле», то есть струнно-щипковый инструмент, схожий с традиционным для греческой кофейни или таверны бузуки $(\mu \pi о v \xi o v ́ \kappa)$, но характеризующийся более вытянутой формой корпуса и более мягким звуком. Можно предположить, что это остроумный намек на схожие явления, но представленные в ином, более «женственном образе».

Вообще, в традиционной греческой культуре существует интересная дихотомия «мужское-женское», выражающаяся через разделение по гендерному признаку песенных, танщевальных жанров и даже музыкальных инструментов. Иногда вечер в кофейне сопровождается музыкой. По традиции исполнителями музыки являются мужчины, особенно если речь идет об игре на бузуки. Женщина может выступать в качестве певицы. Однако, во время зимнего карнавала можно было увидеть и музыкантш. Также любопытным моментом является исполнение женщинами «рембетико». Это удалось увидеть автору статьи в 2006 году на собрании феминисток в Салониках, которое происходило

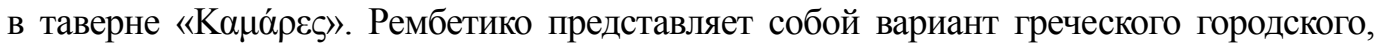
блатного романса, который сопровождается игрой на бузуки и танцем. Возникновение жанра в 20-30 гг. XX в. связано со специализированными малоазийскими кофейнямитеке, в которых нередко курили гашиш. Такие кофейни существовали также в афинском пригороде и порту Пирей. Традиция была привнесена туда выходцами из Малой Азии. Песни нередко исполнялись на криминальном арго с большим количеством турецких заимствований (Пєтрои́лодоৎ 1990). Жанр рембетико рассматривается как исключительно мужской. Исполнение его женщинами до сих пор оценивается почти как вызов патриархальной традиции, но в случае с таверной «Кана́рє૬» эпизод скорее носил элементы карнавальной травестии, так как был приурочен к последней неделе карнавала.

Но все же женские кофейни сильнее размывают традиции, чем мужские. Так, например, «Женская кофейня» в г. Флорина уже мало напоминает традиционную грече-

\footnotetext{
${ }^{1}$ См. фрагмент интервью, взятого у посетительниц кофейни в Кедарес и их мужей в 2018 году: https:// www.hallocy.com/2018/01/29/kafenio-mono-gia-gynekes-se-chorio-tis-pafou-vinteo/\#.X8FjsGUzapo
} 
скую кофейню из-за изысканного интерьера, разнообразия кондитерских изделий, и, самое главное, напитков на основе кофе, хотя «греческий кофе» остается основным.

Подведем итоги. Вариативность названия кофейного напитка встраивается в определенный политический дискурс, открывая различные грани длительного и незавершенного конфликта Греции и Турции, который достигает пика в 1970-е. На лингвистическом уровне подобное явление прослеживается и в других балканских странах, входивших в зону Османского влияния.

Островные наименования кофе отображают особенности традиционной культуры островов и островной идентичности. В случае с Кипром, непосредственно пережившим турецкую оккупацию, сохраняется политически номенклатурный принцип номинации, несмотря на разнородный этнический состав населения острова, который нередко становился «транзитной» зоной между Западом и Востоком в разные времена своей истории. Что касается о. Крит, в данном случае на номинацию не так сильно влияет политический аспект и географически маркированное название относится к совершенно другому напитку-заменителю, тогда как настоящий кофе часто называется более «политкорректными» терминами.

«Кофейный вопрос» также становится поводом для вечной дифференциации «свой-чужой», здесь «патриот - не патриот».

Количество сахара в кофе иногда соотносится с идеей гендера: сладкий кофе определяется как «женский», горький как «мужской».

Для различия традиционной кофейни в новогреческом языке используется осо-

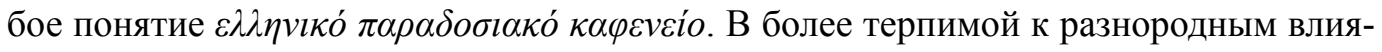
ниям островной традиции фиксируется диалектное слово тюркского происхождения

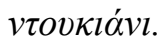

В статье была рассмотрена история и эволюция традиций греческой кофейни. Парадокс греческой кофейни состоял в том, что, родившись из турецкого «кофейного дома», во времена греческого освободительного движения против османского владычества это место нередко становится своеобразным политическим клубом, в котором обсуждаются пути развития нового государства и новой греческой идентичности. Некоторые из кофеен этой эпохи основаны не греками и интегрируют также европейские черты. Политическое противостояние в XIX в. больше касается разнородных течений внутри нового греческого государства: монархисты против сторонников республики, идея национального правительства против навязанных извне королей и т.д. Однако, в XX веке в политический дискурс кофеен через номинацию кофе снова вернется греко-турецкая проблема.

В наше время ракурс политических дискуссий в традиционной греческой кофейне смещается на противостояние различных партий и гендерный вопрос. Последний порождает феномен «женской кофейни», которая, с одной стороны, отражает основные принципы патриархальной мужской кофейни почти в духе карнавальной травестии, но с другой стороны размывает их.

\section{Источники и материалы}

ПМА 2005 - Полевые материалы автора. Россия (июль 2005г.): Ставропольский край, г. Минводы, с. Греческое. Опросная группа - 50 чел.

ПМА 2006 - Полевые материалы автора. Греция (февраль 2006г.): Салоники, Афины, область Фессалия (деревня Полидендро). Опросная группа - 40 человек. 
ПМА 2009 - Полевые материалы автора. Греция (август 2009 г.): о. Крит. Опросная группа 10 человек.

ПМА 2017 - Полевые материалы автора. Греция (июнь 2017 г.): Касторья. Опросная группа 7 человек.

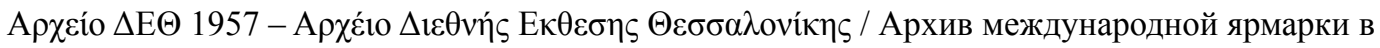
Салониках, 1957 г.

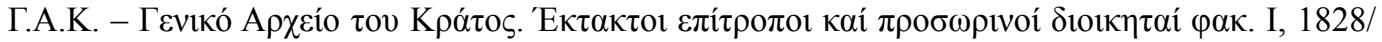
Государственный архив писем периода Греческой революции, досье 1, 1828

Ведюшкин, Юсим 2013 - Ведюшкин В.А., Юсим М.А. (отв. ред.) Всемирная история: в 6 томах. Том 3: Мир в раннее Новое время. Москва: Наука 2013. 854 с.

Попов 2020 - Попов А.П. Понтийские греки. Доступ: https://papounidis.com/pontijskie-greki/ (дата обращения: 16.11.2020).

Kakissis 2020 - Kakissis I. Dont-call-it-turkish-coffee-unless-of-course-it-is / The Salt. Доступ: https://www.npr.org/sections/thesalt/2013/04/27/179270924/dont-call-it-turkish-coffee-unlessof-course-it-is (дата обращения: 02.11.2020).

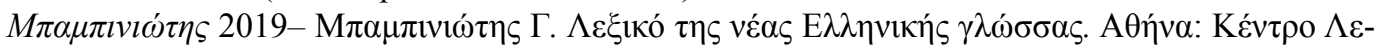

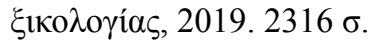

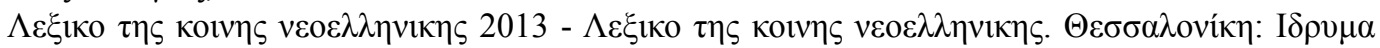

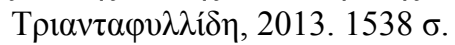

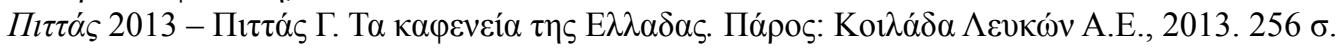

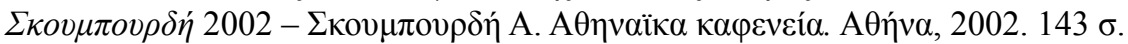

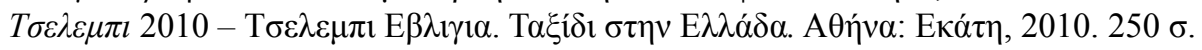

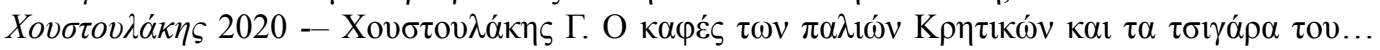
ßovvov́! Доступ: https://www.cretanmagazine.gr/o-kafes-ton-palion-kritikon-kai-ta-tsigaratoy-voynoy/ (дата обращения: 02.11.2020).

\section{Научная литература}

Мартынова М.Ю., Фаис-Леутская О.Д. Антропология питания: судьбы мясных деликатесов в Европе // Этнографическое обозрение, 2020. № 4. С. 5-14.

Павловская А.В. Нужна ли нам наука о еде? // Еда и культура. М.: Центр по изучению взаимодействия культур, 2015. С. 7-44.

Cowan B. The Social life of Coffee. The emergence of the British coffeehouse. London: Yale University Press New Haven, 2005. 384 p.

Karakatsanis L. Turkish-Greek Relations: Rapprochement. Civil Society and the Politics of Friendship. USA: Routledge, 2014. 284 p.

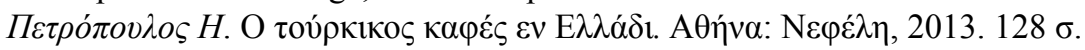

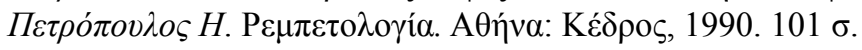

Sidneva, Svetlana A.

\section{Greek Coffee and Coffee House Traditions in Contemporary Political Discourse}

DOI: $10.33876 / 2311-0546 / 2021-3 / 274-286$

The article is dedicated to coffee and coffee houses in modern Greek culture. Names of coffee types among the Greeks are embedded in a specific political discourse that sheds light on the long and unfinished conflict between Greece and Turkey. Similar processes of re-naming drinks with ethnonyms in their names are observed in other Balkan countries. A traditional Greek coffee house has its roots in the Turkish tradition. During the Greek liberation movement against the Ottomans, it often becomes a place to discuss the development of a new state and Greek identity. Nowadays, the focus of discussions is shifting 
to the confrontation between different parties and the gender issue, which even leads to the phenomenon of a "women's coffee house", which is first explored in the present study. On the one hand, a "women's coffee house" violates tradition, but on the other, it once again reveals the constant nature and mechanisms of modern Greek traditional culture.

Keywords: Greek coffee, Cypriot coffee, Cretan coffee, Greek traditional coffee house, women's coffee house, political discourse, gender issue

For Citation: Sidneva, S.A. 2021. Greek Coffee and Coffee House Traditions in Contemporary Political Discourse. Herald of Anthropology (Vestnik Antropologii) 3: 274-286.

Author Info: Sidneva, Svetlana A. - Ph.D. in Philology, Associate Professor of the Italian Language Department, Faculty of Foreign Languages and Regional Studies, Moscow State University Lomonosov (119991 Moscow, Leninskie Gory 1, 13). E-mail: lucia1980@, yandex.ru. ORCID: https://orcid.org/0000-0002-2937-5434

\section{References}

Babiniotis, G. 1998. Lexico neas ellinikis glossas [Modern Greek Dictionary]. Ahina: Kendro Lexikologias.

Chelibi, Evliya. 2010. Taxidi stin Ellada [Travel in the Greece]. Athina: Ekati.

Cowan, B. 2005. The Social life of Coffee. The emergence of the British coffeehouse. London: Yale University Press New Haven.

Houstoulakis, G. O kaffes ton palion kritikon kai ta tsigara tou ...vounou! [Coffee of the Old Cretans and the cigar of...mountins] https://www.cretanmagazine.gr/o-kafes-ton-palion-kritikonkai-ta-tsigara-toy-voynoy/ (accessed: 02.11. 2020).

Karakatsanis, L. 2014. Turkish-Greek Relations: Rapprochement. Civil Society and the Politics of Friendship. USA: Routledge.

Kakissis, I. Dont-call-it-turkish-coffee-unless-of-course-it-is / The Salt: https://www.npr.org/ sections/thesalt/2013/04/27/179270924/dont-call-it-turkish-coffee-unless-of-course-it-is (accessed: 02.11 .2020 )

Lexico tis Koinis Ellinikis. 2013. [Modern Greek Dictionary]. Thessaloniki: Idryma Triandaffilidi.

Martynova, M. YU., Fais-Leutskaya, O.D. 2020. Antropologiya pitaniya: sud'by myasnyh delikatesov v Evrope [Anthropology of Food: Destinies of Meat Delicasies in Europe]// Etnograficheskoe obozrenie 4: 5-14.

Pavlovskaya, A.V. 2015. Nuzhna li nam nauka o ede? [Do We need Food Science?]. In Eda i kul'tu$r a$, edited by A.V.Pavlovskaya, I.I. Rucinskaya, N.A Karelina,, G.E. Smirnova, E.G. Domnina,. and I.V. Pavlovskij, 7-24. Moscow: Centr po izucheniyu vzaimodejstviya kul'tur.

Pittas, G. 2013. Ta kafeneia tis Elladas [The Greek Coffee Houses]. Paros: Koilada Leukon A.E.

Petroupolos, I. 2013. O Tourkikos kaffes en Elladi [The Turc Coffee in Greece]. Athens: Nefeli.

Petroupolos, I. 1990. O Rembetologia [Rembetique Science]. Athens: Kedros.

Popov, A.P. Pontijskie greki [Pontic Greeks]. https://papounidis.com/pontijskie-greki/ (accessed:16.11.2020)

Skoumburdi, A. 2002. Athenaika kafeneia [Athens Coffee Houses]. Athens.

Vedyushkin, V.A., Yusim, M.A., eds. 2013. Vsemirnaya istoriya: v 6 tomah. Vol 3, Mir v rannee Novoe vremya [World history: in 6 volumes. Volume 3: The World in Early Modern Times]. Moscow: Nauka. 